\title{
NUBI, an interferon-inducible protein, mediates anti-proliferative actions and apoptosis in renal cell carcinoma cells through
} cell-cycle regulation

\author{
T Hosono', T Tanaka*,', K Tanji', T Nakatani' and T Kamitani ${ }^{3}$ \\ 'Department of Urology, Osaka City University Graduate School of Medicine, Osaka, Japan; ${ }^{2}$ Department of Neuropathology, Institute of Brain Science, \\ Hirosaki University Graduate School of Medicine, Hirosaki, Japan; ${ }^{3}$ Center for Molecular Chaperone, Medical College of Georgia, Augusta, GA, USA
}

BACKGROUND: NEDD8 ultimate buster I (NUBI) is an interferon (IFN)-inducible protein that downregulates NEDD8 expression and its conjugation system. Although overexpression of NUBI induces a growth-inhibitory effect in cells, the mechanisms underlying the anti-mitogenic actions of NUBI in cancer cells remain uncertain. We investigated the anti-cancer effects of NUBI in human renal cell carcinoma (RCC) cells.

METHODS: Nine human RCC cells were used for this study. The proliferation of RCC cells exposed to IFN- $\alpha$ was measured by watersoluble tetrazolium salt assay. The expression level of NUBI in cells was measured by quantitative reverse transcriptase PCR or western blot analysis. Apoptosis and cell-cycle analysis were performed by flow cytometry. Silencing of NUBI was performed using a small interfering RNA.

RESULTS: Both NUBI messenger RNA and protein were significantly induced by IFN- $\alpha$ in seven out of nine selected RCC cell lines, and the NUBI expressions induced by IFN- $\alpha$ correlated positively with cell growth inhibition. Overexpression of NUBI remarkably induced S-phase transition during cell cycle and apoptosis in IFN- $\alpha$-resistant A498 cells, in which NUBI is not induced by IFN- $\alpha$. The expression levels of two cell-cycle regulator proteins, cyclin E and p27, were increased under the aforementioned conditions. The knockdown of NUBI enhanced cell proliferation of IFN- $\alpha$-resistant A498 cells and suppressed IFN- $\boldsymbol{\alpha}$-induced growth inhibition in IFN- $\alpha$-sensitive 4TUHR cells.

CONCLUSION: NUBI may be a key factor involved not only in cell growth inhibition by IFN- $\alpha$ in RCC cells but also in the anti-cancer effect against IFN- $\alpha$-resistant RCC cells.

British Journal of Cancer (2010) I 02, 873-882. doi:10.1038/sj.bjc.6605574 www.bjcancer.com

Published online 16 February 2010

(c) 2010 Cancer Research UK

Keywords: NUBI; IFN- $\alpha$; apoptosis; cell cycle; RCC

Renal cell carcinoma (RCC) is the most common cancer of the kidney (Parkin et al, 2005). Approximately $30 \%$ of patients with RCC present with metastatic disease (Motzer et al, 1996; Lam et al, 2005), and the 5-year survival rate for those with metastatic RCC is $<10 \%$ (Motzer et al, 1996). Immunotherapy based on interferon alpha (IFN- $\alpha$ ) and/or interleukin-2 has been widely adopted as the first-line treatment for metastatic RCC and clinical benefits including long-term complete remission have been demonstrated, but the prognosis of these patients is still poor (Negrier et al, 1998; McDermott et al, 2005).

Recently, several alternative treatments were developed for metastatic RCC. Vascular endothelial growth factor (VEGF) is a potent pro-angiogenic protein that is responsible for increased vasculature and tumour growth in RCC. Fundamentally, a mutation in the von Hippel-Lindau tumour-suppressor gene

\footnotetext{
* Correspondence: Dr T Tanaka, Department of Urology, Osaka City University Graduate School of Medicine, 1-4-3, Asahimachi, Abeno-ku, Osaka 545-8585, Japan; E-mail: tomoaki826@msic.med.osaka-cu.ac.jp Received 21 August 2009; revised 3 December 2009; accepted 18 January 2010; published online 16 February 2010
}

induces overexpression of VEGF through accumulation of hypoxia-inducible factor (HIF)-1 in RCC (Maxwell et al, 1999; Kerbel, 2008). Several novel agents that inhibit the VEGF signalling cascade, such as sorafenib, sunitinib and bevacizumab, have been found to exert significant anti-tumour effects and provide meaningful clinical benefits (Escudier et al, 2007; Hudes et al, 2007; Motzer et al, 2007; Rini et al, 2008). Furthermore, temsirolimus and everolimus, inhibitors of the mammalian target of rapamycin (mTOR), which block the phosphoinositide 3-kinase (PI3K)/AKT signalling pathway involved in numerous cellular functions including cell proliferation, survival and angiogenesis, have been found to be effective agents against advanced RCC in the clinical setting (Hudes et al, 2007; Amato et al, 2009). Although molecular targeting therapies against the VEGF or mTOR signalling pathway have revolutionised the treatment of advanced RCC, no curative therapy has yet been established. Moreover, although IFN- $\alpha$ is the classic standard for treating RCC, the antitumour action of IFN- $\alpha$ exerted through a direct inhibition of tumour growth and biological response modifiers remains to be clarified. Hence, identifying the molecules critical for immunotherapy with IFN- $\alpha$ is still crucial to developing treatments for metastatic RCC. 
NEDD8, one of the ubiquitin-like proteins, reportedly forms conjugates with cullin family proteins and thereby activates an Skp1-Cullin-F-box (SCF) ubiquitin protein ligase complex that catalyses the ubiquitination of many cellcycle regulators, for example, cyclin E, p21, p73 and p27 (Singer et al, 1999; Podust et al, 2000; Wang et al, 2005; Watson et al, 2006).

NEDD8 ultimate buster 1 (NUB1) is a NEDD8-interacting protein composed of 601 amino-acid residues with a calculated molecular mass of $69.1 \mathrm{kDa}$. It is an IFN-inducible protein and predominantly localises in the nucleus. Biologically, NUB1 recruits NEDD8 and its conjugates to the proteasome for degradation and negatively regulates the NEDD8 conjugation system (Kamitani et al, 2001; Kito et al, 2001; Tanaka et al, 2003). Furthermore, NUB1 is expressed in some cancer cell lines, including rectal adenocarcinoma, neuroblastoma, malignant lymphoma, cervical adenocarcinoma and RCC (Kito et al, 2001). Kito et al have also shown that the expression of NUB1 is induced by IFN- $\beta$ in certain cell lines and that exogenous overexpression of NUB1 inhibits proliferation of U2OS cells, which are deficient in endogenous NUB1 expression (Kito et al, 2001). Recently, NUB1 has been reported to inhibit the formation of inclusions such as the Lewy bodies seen in brains of patients with Parkinson's disease (Tanji et $a l, 2006)$. As the expression of NEDD8 is downregulated by NUB1, the expression level of NUB1 may control many important biological events, including cell-cycle progression. However, the biological functions of NUB1 in cancer cells remain largely unknown.

We investigated the relations of NUB1 protein induction by IFN- $\alpha$ with growth inhibition of cells exposed to IFN- $\alpha$ and the biological actions of NUB1 (e.g., cell-cycle regulation, induction of apoptosis) in RCC cell lines.

\section{MATERIALS AND METHODS}

\section{Cell lines and cell culture}

Human RCC cell lines ACHN (CRL-1611), Caki-1(HTB-46), A-498(HTB-44) and 786-0 (CRL-1932) were obtained from the American Type Culture Collection (Manassas, VA, USA). RCC10RGB (10RGB), OS-RC2 and TUHR4TKB (4TUHR) were purchased from RIKEN Cell Bank (Tsukuba Science City, Tokyo, Japan). The OCUU1 and OCUU3 RCC cell lines were established in our laboratory from Japanese RCC patients. Cell lines were maintained in Dulbecco's modified Eagle's medium (Sigma, St. Louis, MO, USA) supplemented with $10 \%$ foetal bovine serum (HyClone, Logan, UT, USA), $100 \mathrm{U} \mathrm{ml}^{-1}$ of penicillin and $100 \mu \mathrm{g} \mathrm{ml}^{-1}$ of streptomycin (Gibco, New York, NY, USA) at $37^{\circ} \mathrm{C}$ in a humidified atmosphere containing $5 \% \mathrm{CO}_{2}$.

\footnotetext{
Antibodies

Rabbit polyclonal anti-NUB1 antibody was obtained from Biomol (Plymouth Meeting, PA, USA). Rabbit polyclonal anti-NEDD8 antibody was generated by immunisation with a glutathione $S$-transferase-fusion protein of human NEDD8, followed by affinity purification (Kamitani et al, 2001). Mouse monoclonal anti-cyclin D1 and anti-cyclin E antibodies were obtained from Thermo Fisher Scientific (Cheshire, UK). Mouse monoclonal anti-p21 and anti-p53 antibodies were purchased from Cell Signaling Technology (Beverly, MA, USA). Mouse monoclonal anti-p27 antibody was from BD Biosciences Pharmingen (San Diego, CA USA). Mouse monoclonal anti-CDK2 and anti-CDK4 antibodies were from Medical \& Biological Laboratories (Nagoya, Japan). Mouse monoclonal anti- $\beta$-actin antibody was from Abcam (Cambridge, UK).
}

\section{Cell-proliferation assay}

Cells $\left(3-5 \times 10^{3}\right.$ cells per well) were incubated in 24-well culture plates (Corning Inc., New York, NY, USA) in $500 \mu \mathrm{l}$ of medium with or without $1000 \mathrm{U} \mathrm{ml}^{-1}$ of IFN- $\alpha$ (Dainippon Sumitomo Pharma Inc., Tokyo, Japan). After culturing for 24, 48, 72, 96 or $120 \mathrm{~h}$, the supernatant was removed, and cell-growth inhibition was determined using water-soluble tetrazolium salt (WST-1) assay (Dojindo Laboratories, Kumamoto, Japan) according to the manufacturer's instructions. Absorbance was measured at $450 \mathrm{~nm}$ using a microplate reader. All assays were carried out in triplicate.

\section{Real-time PCR analysis of NUB1}

Total RNA was extracted from RCC cells using an RNAqueous kit (Ambion Inc., Austin, TX, USA) in accordance with the manufacturer's instructions and reverse transcribed into cDNA with random hexamers using a high-capacity cDNA reverse transcription kit (Applied Biosystems, Foster City, CA, USA). The cDNA was quantified by real-time PCR using the Prism 7300 Sequence Detection System (Applied Biosystems). The PCR primers and TaqMan probes for NUB1 (assay ID: Hs00211567_m1, Applied Biosystems) were purchased from Applied Biosystems. $\beta$-actin (assay ID: 4333762-0711022, Applied Biosystems) was used as the internal control for data normalisation.

\section{Western blotting}

Cells were harvested and whole-cell lysates were prepared using the PRO-PREP protein extraction solution (iNtRON Biotechnology, Gyeonggi-do, Korea) in accordance with the manufacturer's instructions. Protein concentrations of samples were determined by the bicinchoninic acid protein assay (BioRad, Hercules, CA, USA). Protein samples $(20 \mu \mathrm{g}$ of each protein) were treated at $50^{\circ} \mathrm{C}$ for $1 \mathrm{~h}$ in $2 \%$ SDS-treating solution containing 5\% $\beta$-mercaptoethanol and separated in $10 \%$ SDSpolyacrylamide gels and transferred onto nitrocellulose membranes. Membranes were blocked for $1 \mathrm{~h}$ at room temperature with Tris-buffered (TBS) containing $0.05 \%$ Tween 20 and $5 \%$ non-fat dried milk, and probed overnight at $4{ }^{\circ} \mathrm{C}$ with primary antibodies under manufacturer-recommended conditions. Immunoblots were washed with TBS containing $0.05 \%$ Tween 20 and $1 \%$ non-fat milk and incubated with secondary antibodies conjugated with horseradish peroxidase against mouse IgG or rabbit IgG (Santa Cruz Biotechnology, Santa Cruz, CA, USA) for $1 \mathrm{~h}$ at room temperature. Immunoreactive proteins were visualised using the ECL detection system (Pierce, Rockford, IL, USA). Each western blot analysis was performed in triplicate.

\section{Apoptosis analysis}

The generation of FLAG-NUB1 in pcDNA3 has been described (Tanaka et al, 2003). Cells were transfected with $6 \mu \mathrm{g}$ of pcDNA3/ FLAG-NUB1 or pcDNA3 (control) using $18 \mu \mathrm{l}$ of Fugene 6 reagent (Roche, Mannheim, Germany) according to the manufacturer's protocol. All transfections were carried out in a condition with serum. The transfectants were stained $24 \mathrm{~h}$ after transfection using the APO-DIRECT kit (BD) in accordance with the manufacturer's instructions. In brief, cells were washed in PBS and resuspended in $1 \%(w / v)$ paraformaldehyde in PBS. After incubation on ice, aliquots of cells were centrifuged and resuspended in $70 \%(\mathrm{v} / \mathrm{v})$ ice-cold ethanol. The cell suspensions were incubated in staining solution containing fluorescein isothiocyanate-dUTP, terminal deoxynucleotidyl transferase enzyme and reaction buffer for $3 \mathrm{~h}$ at $37^{\circ} \mathrm{C}$. After washing with rinse buffer, the treated cells were 
A

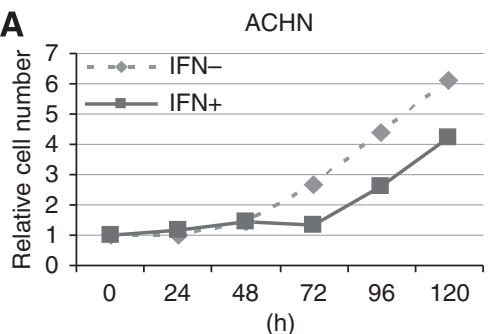

Caki-1

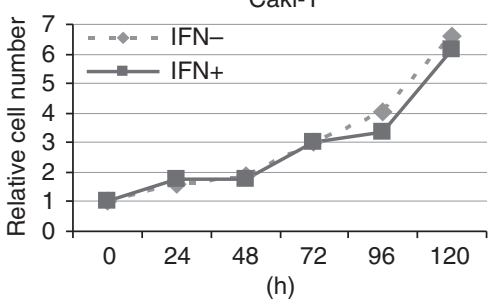

A-498

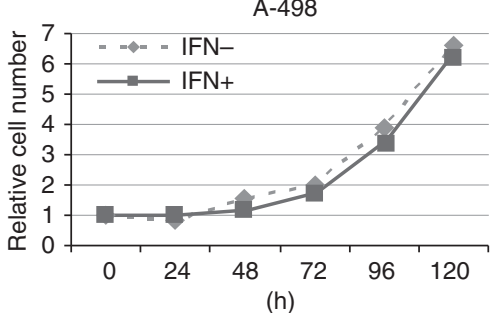

10RGB

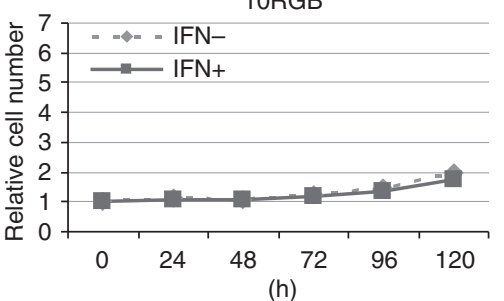

$786-0$

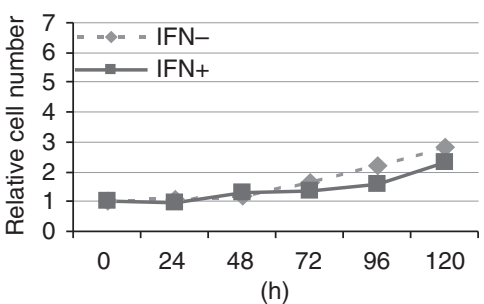

OCUU1

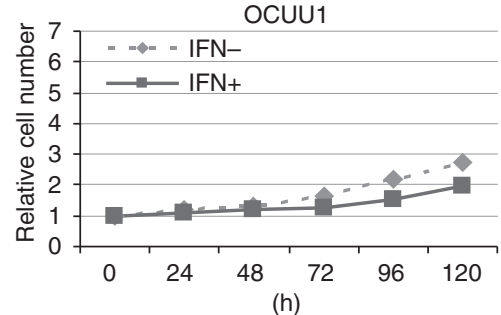

OCUU3

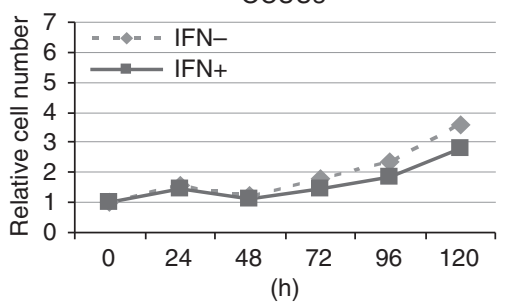

OS-RC2

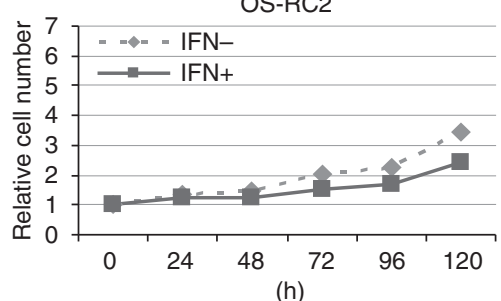

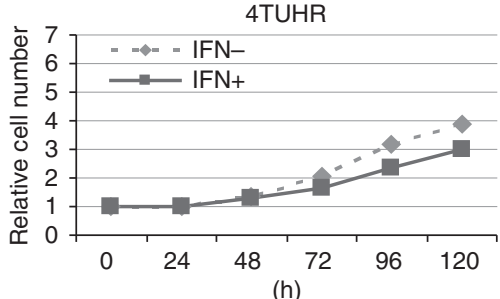

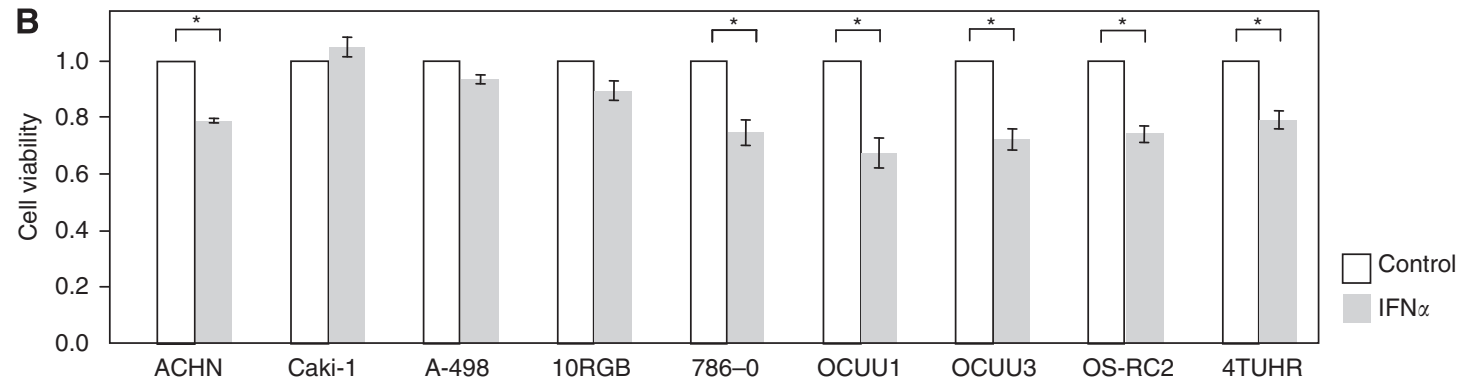

Figure I Growth inhibition of nine renal cell carcinoma (RCC) cell lines after interferon alpha (IFN- $\alpha$ ) treatment. As described in the Materials and Methods section, the number of viable RCC cells with or without $1000 \mathrm{IU} \mathrm{ml} \mathrm{ml}^{-1} \mathrm{IFN}-\alpha$ treatment for $0,24,48,72,96$ or I20 h was determined by water-soluble tetrazolium salt (WST-I) assay. (A) Values measured at $0 \mathrm{~h}$ with or without IFN- $\alpha$ in each cell line were defined as I. Three individual experiments were performed. (B) Values measured after $72 \mathrm{~h}$ without IFN- $\alpha$ in each cell line were defined as I (control). Results are expressed as means \pm s.d. $* P<0.05$ compared with the control (Student's $t$-test, $n=3$ ). 
finally stained with propidium iodide. Thereafter, all samples were analysed with a FACSCalibur flow cytometer with CellQuest software (BD Biosciences, Mountain View, CA, USA).

\section{Cell-cycle analysis}

Cells were transfected with pcDNA3/FLAG-NUB1 or pcDNA3 (control) as described above. After $16 \mathrm{~h}$, the cells were harvested and stained with propidium iodide using Cycle Test plus (BD Biosciences) according to the manufacturer's protocol. Samples were placed on ice and immediately analysed on FACSCalibur with ModFit LT ver. 2.0 software (BD Bioscience) to separate G0/G1, S, $\mathrm{G} 2 / \mathrm{M}$ and hypodiploid nuclei.

\section{NUB1 silencing using siRNAs}

The NUB1 short interfering RNAs (siRNAs) and negative control siRNAs were purchased from Applied Biosystems (catalogue no. AM16708A and AM4611, respectively). Each siRNA was transfected into subconfluent cells using Lipofectamine 2000 (Invitrogen Life Technologies, Carlsbad, CA, USA) according to the manufacturer's instructions. At $72 \mathrm{~h}$ after transfection, the transfected cells were harvested, followed by western blotting or viable-cell counting.

\section{Statistical analysis}

Statistical analysis was performed with JMP 7.0 software. (SAS Institute, Cary, NC, USA). Data were expressed as means \pm s.d.
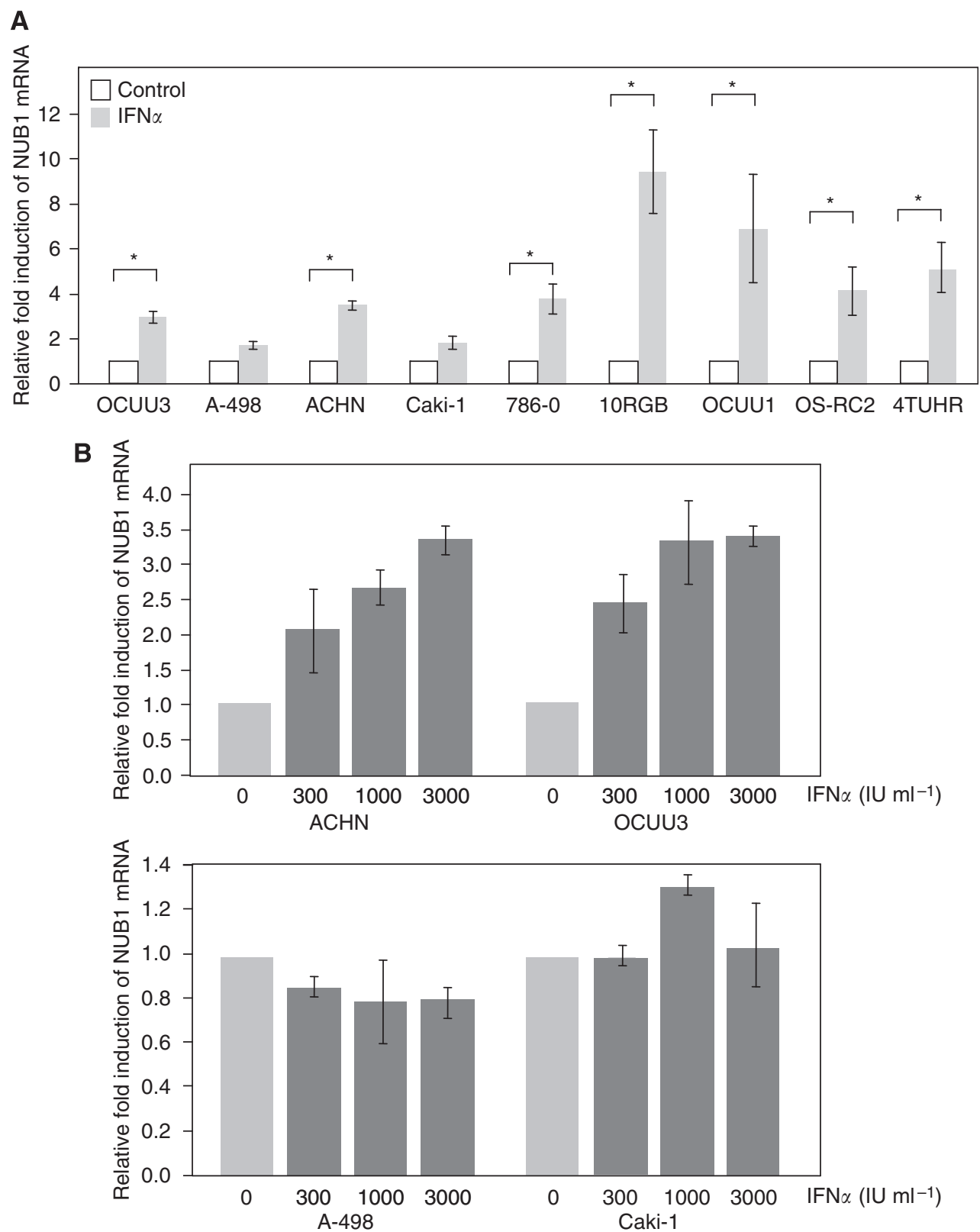

Figure 2 Effects of interferon alpha (IFN- $\alpha$ ) treatment on NEDD8 ultimate buster I (NUBI) mRNA expression levels in renal cell carcinoma (RCC) cell lines. (A) Nine RCC cell lines were treated with or without $1000 \mathrm{IU} \mathrm{ml}^{-1}$ of IFN- $\alpha$ for $6 \mathrm{~h}$. The NUBI expression levels of all samples were then determined using Taqman real-time PCR. Three individual experiments were performed. Values are means \pm s.d. of the gene expression level relative to that in the control, given an arbitrary value of I. * $P<0.05$ (Student's $t$-test, $n=3$ ). (B) IFN- $\alpha$-sensitive (ACTHN, OCUU3) and -resistant (A498, caki-I) RCC cell lines were incubated for $19 \mathrm{~h}$ with various concentrations of IFN- $\alpha$ as indicated. NUBI expression levels were determined by the same method as above. 
$\underset{\text { OPEN }}{\mathrm{BJC}} \cap$

Statistically significant differences were determined by Student's $t$-test and the correlation between growth inhibition and NUB1 induction by IFN- $\alpha$ was assessed by regression analysis.

\section{RESULTS}

\section{IFN- $\alpha$ responsiveness of RCC cell lines}

A498, caki-1 and 10RGB cells were almost resistant to IFN- $\alpha$ mediated cell-growth inhibition compared with other cell lines. In other cell lines, growth was reduced to $\sim 70-80 \%$ of that in controls after culture for $72 \mathrm{~h}$ (Figure 1B). The A498, caki-1 and 10RGB cell lines were thus considered to be IFN- $\alpha$ resistant, whereas other cell lines were considered to be IFN- $\alpha$ sensitive.

\section{IFN- $\alpha$ induces expression of NUB1 messenger RNA in IFN- $\alpha$-sensitive RCC cell lines}

The induction rates of NUB1 mRNA in IFN- $\alpha$-resistant cell lines, such as A498 and caki-1, were much lower than those of other cell lines (Figure 2A). In IFN- $\alpha$-sensitive cell lines, such as OCUU3 and ACHN, levels of NUB1 mRNA induced by IFN- $\alpha$ were increased in a dose-dependent manner (Figure 2B, upper panel). In contrast, levels of NUB1 mRNA were not changed significantly by treatment with IFN- $\alpha$ in IFN- $\alpha$-resistant cells, such as A498 and caki-1 (Figure 2B, lower panel).
Positive correlation between IFN- $\alpha$-induced growth inhibition and IFN- $\alpha$-induced protein expression of NUB1

Protein expression of NUB1 in both IFN- $\alpha$-sensitive and -resistant cell lines was determined by western blot analysis using an anti-NUB1 antibody. IFN- $\alpha$ induced protein expression of NUB1 in seven RCC cell lines (786-0, OCUU3, 10RGB, OS-RC2, OCUU1, ACHN and 4TUHR) but not in caki-1 cells (1.18-fold) or A498 cells (1.06-fold). It is noteworthy that IFN- $\alpha$ induced NUB1 protein in IFN- $\alpha$-sensitive cell lines, but not in IFN- $\alpha$-resistant cell lines (except for 10RGB) (Figures 3A and B). Next, single linear regression analysis revealed that levels of NUB1 induction by IFN- $\alpha$ tended to predict responses to IFN- $\alpha$. This tendency was not statistically significant when all RCC cell lines were considered $\left(P=0.09\right.$ and $\left.R^{2}=0.34\right)$. However, it was significant when 10RGB was omitted from the analysis $\left(P<0.01\right.$ and $\left.R^{2}=0.74\right)$ (Figure $3 C$ ).

\section{Overexpression of NUB1 induces apoptosis in A498 RCC cells}

A498 cells, in which NUB1 was not induced by IFN- $\alpha$, were transfected with pcDNA3/FLAG-NUB1 or pcDNA3 (control), and an apoptosis assay was performed by flow cytometry (FCM) $24 \mathrm{~h}$ after the transfection. Western blot analysis using the anti-NUB1 antibody revealed that expression level of NUB1 protein in A498 cells transfected with pcDNA3/FLAG-NUB1 was almost three times more than that in control mock cells (Figure 4A). Moreover, the

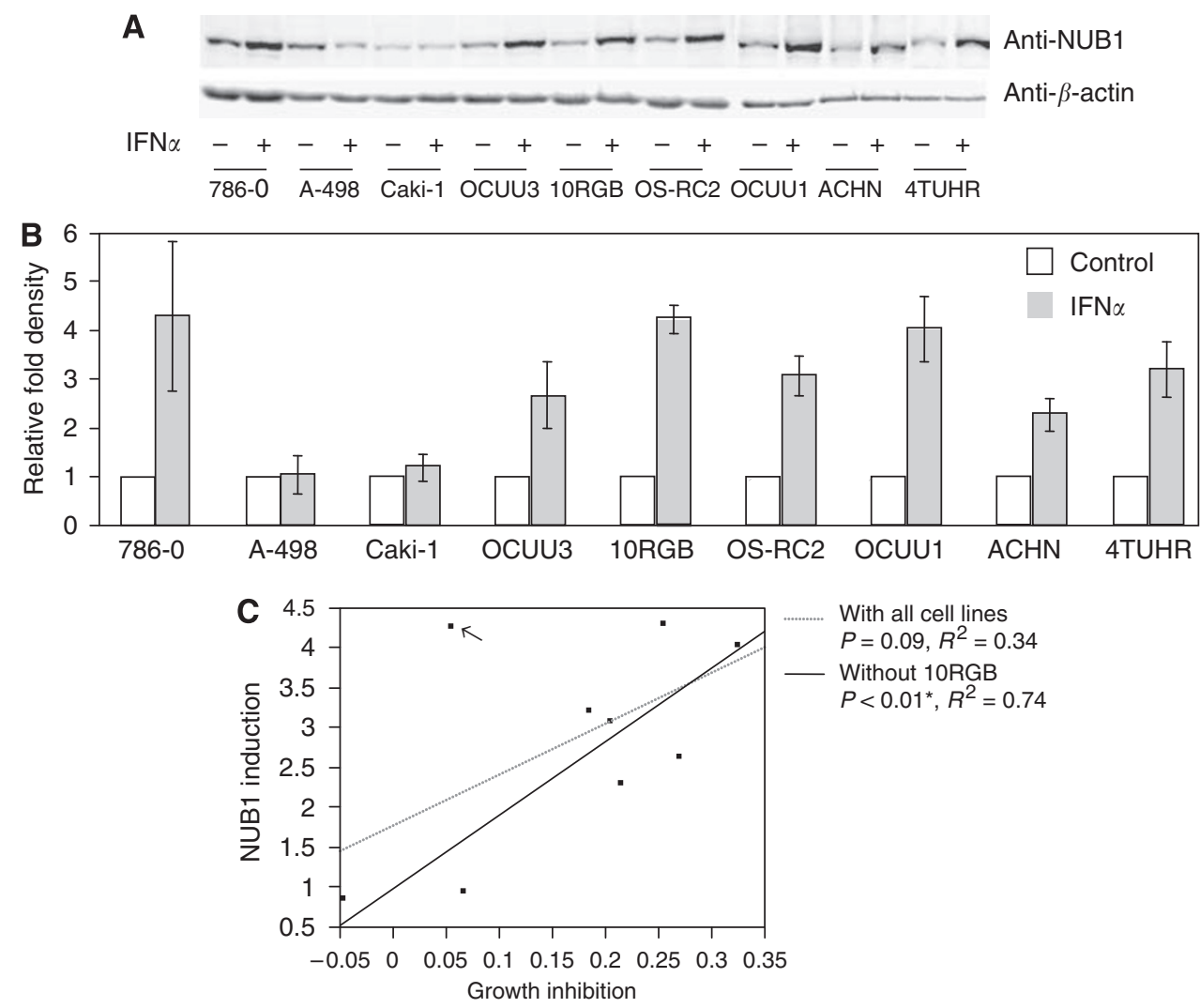

Figure 3 Correlations of interferon alpha (IFN- $\alpha$ )-induced cell growth inhibition and IFN- $\alpha$-induced NEDD8 ultimate buster I (NUBI) expression in renal cell carcinoma (RCC) cell lines. (A) Cells were treated with or without $3000 \mathrm{U} \mathrm{ml}^{-1}$ IFN- $\alpha$ for $24 \mathrm{~h}$. Total cell lysates were prepared from each cell line and analysed by western blotting using an anti-NUBI antibody to detect NUBI protein (upper panel). To demonstrate equal loading amounts of total cell lysates, western blotting using anti- $\beta$-actin antibody was also performed (lower panel). (B) To quantitatively evaluate the data shown in (A), a densitometry analysis was performed. NUBI expression values are normalised by the $\beta$-actin level in each cell line and presented as the relative fold compared with the control. Three individual experiments were performed and means \pm s.d. are presented. (C) The analysis was performed using the inhibition values of cell proliferation presented in Figure IB and the induction ratios of NUBI protein by IFN- $\alpha$ shown in (B). Lines represent RCC cell samples with (solid line: coefficient $=0.34, P=0.09$ ) and without (dotted line: coefficient $=0.74, * P<0.0$ I) the IORGB cell line (arrow). 
A

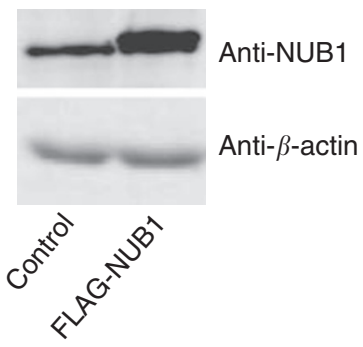

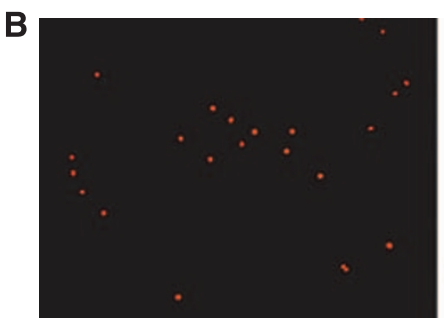

Control

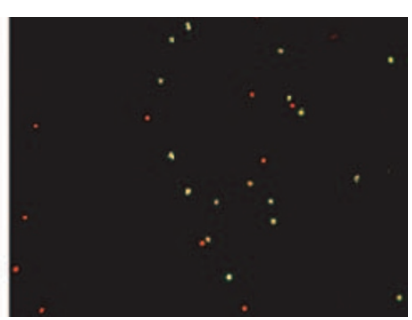

FLAG-NUB1

Control
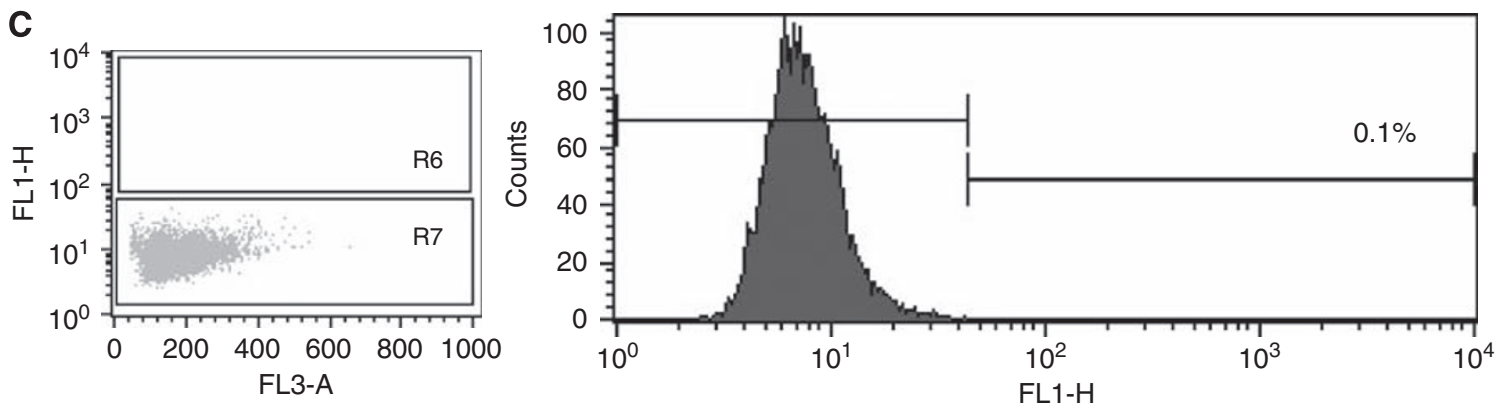

FLAG-NUB1
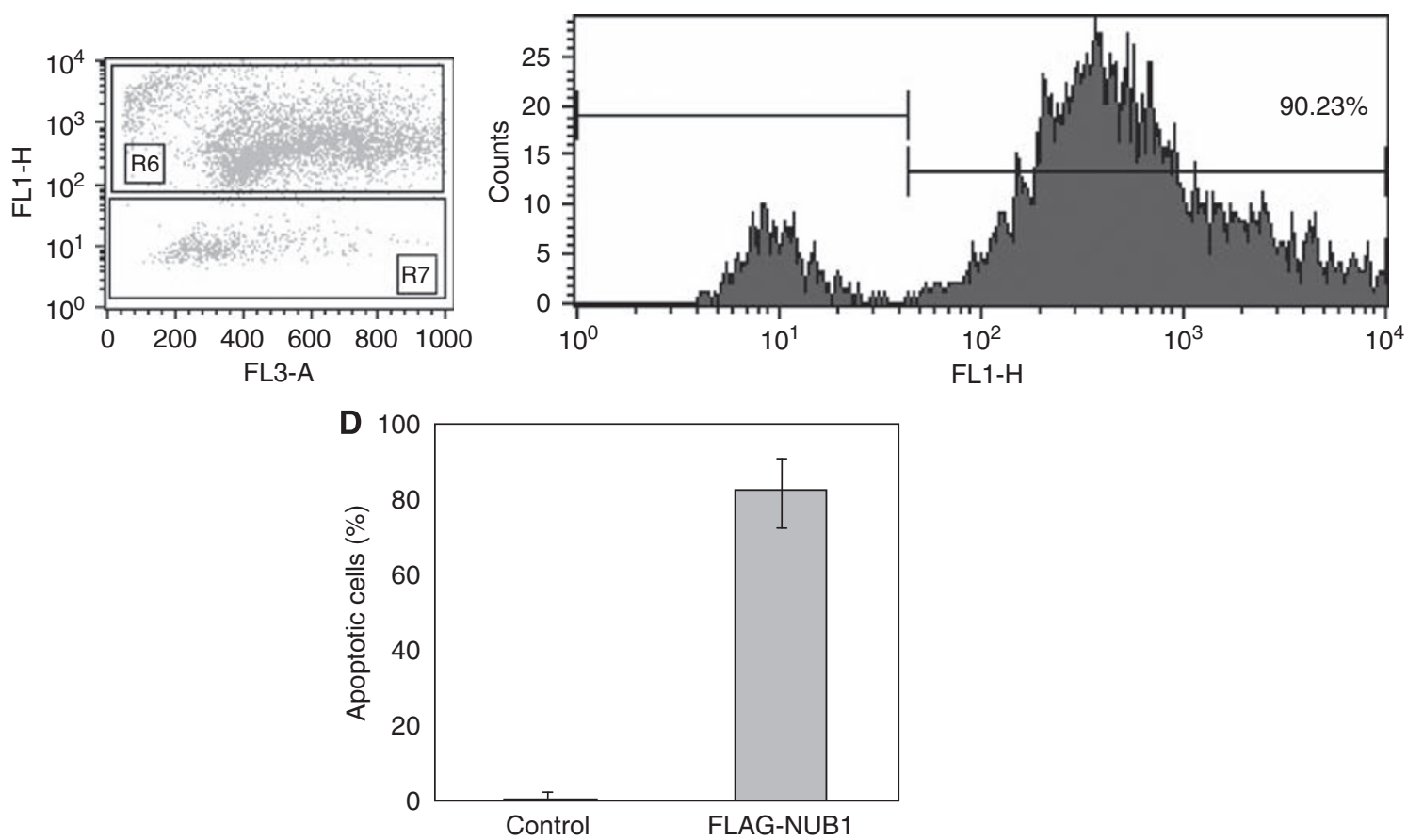

Figure 4 Overexpression of NEDD8 ultimate buster I (NUBI) induces apoptosis in A498 cells. A498 cells were transiently transfected with pcDNA3 empty vector (control) or pcDNA3/FLAG-NUBI. (A) Total cell lysates were analysed by western blotting using anti-NUBI antibody (upper panel) or anti- $\beta$-actin antibody (lower panel). (B) Representative photograph of A498 cells stained for apoptosis with the terminal deoxynucleotidyltransferasemediated dUTP-fluorescein isothiocyanate (FITC) nick end-labelling (TUNEL) method. Apoptotic cells are shown by the green fluorescence of FITC Nuclear and mitochondrial DNA and ribosomal RNA are counterstained and shown by the red fluorescence of propidium iodide. (C) Measurement of apoptotic cells in the A498 cell line transfected with pcDNA3 empty vector (upper panel, control) or pcDNA3/FLAG-NUBI (lower panel) using flow cytometry. (D) Three individual experiments were performed, and the percentage of apoptosis in A498 cells is represented as mean \pm s.d.

flow cytometry analysis showed that up to $90 \%$ of A498 cells, which overexpressed FLAG-NUB1, underwent apoptosis (Figures 4B-D). We also conducted the same analysis with overexpression of FLAG-NUB1-long (NUB1L), an alternative splicing variant, and obtained the same results under these conditions as with FLAG-NUB1 (data not shown).

\section{Overexpression of NUB1 alters cell cycle with S-phase arrest through cell-cycle regulator proteins}

To examine the process associated with the apoptotic effect of NUB1, we initially performed cell-cycle analysis in A498 cells transfected with pcDNA3/FLAG-NUB1 or empty control vector. 
BJC $\cap$

Overexpression of NUB1 increased the cell population in S phase while decreasing those in G0/G1 and G2/M phases, compared with the control (Figure 5A). Next, we examined the cell-cycle regulator proteins that were involved in the S-phase transition induced by NUB1 overexpression. Western blot analysis revealed the expression levels of cyclin E and p27 to be increased in A498
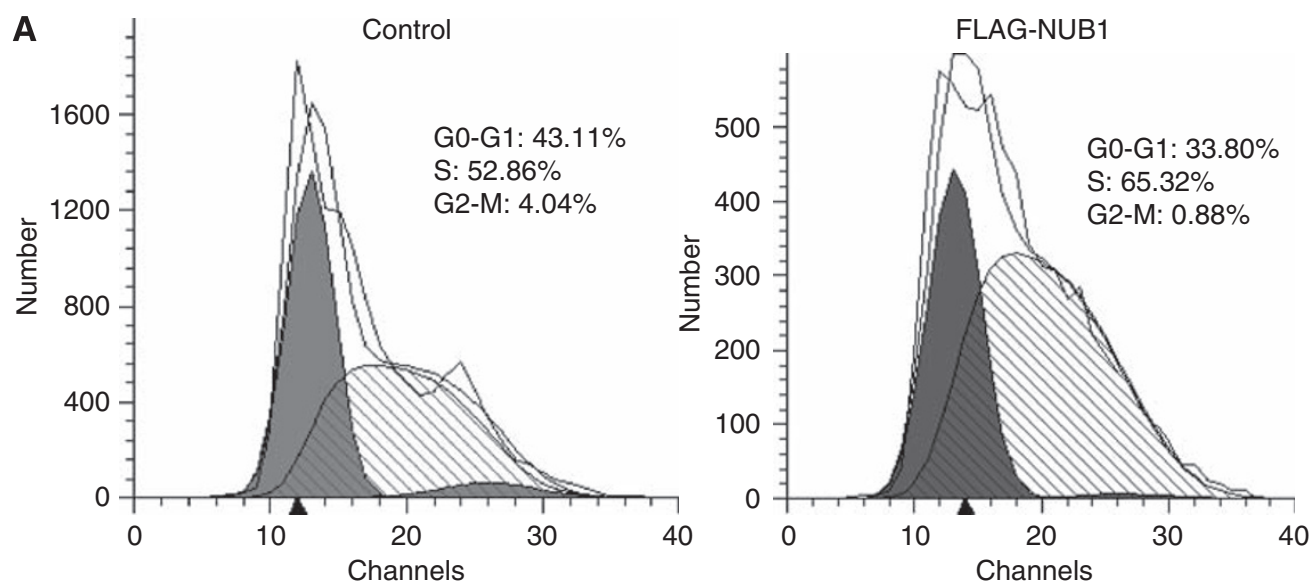

B

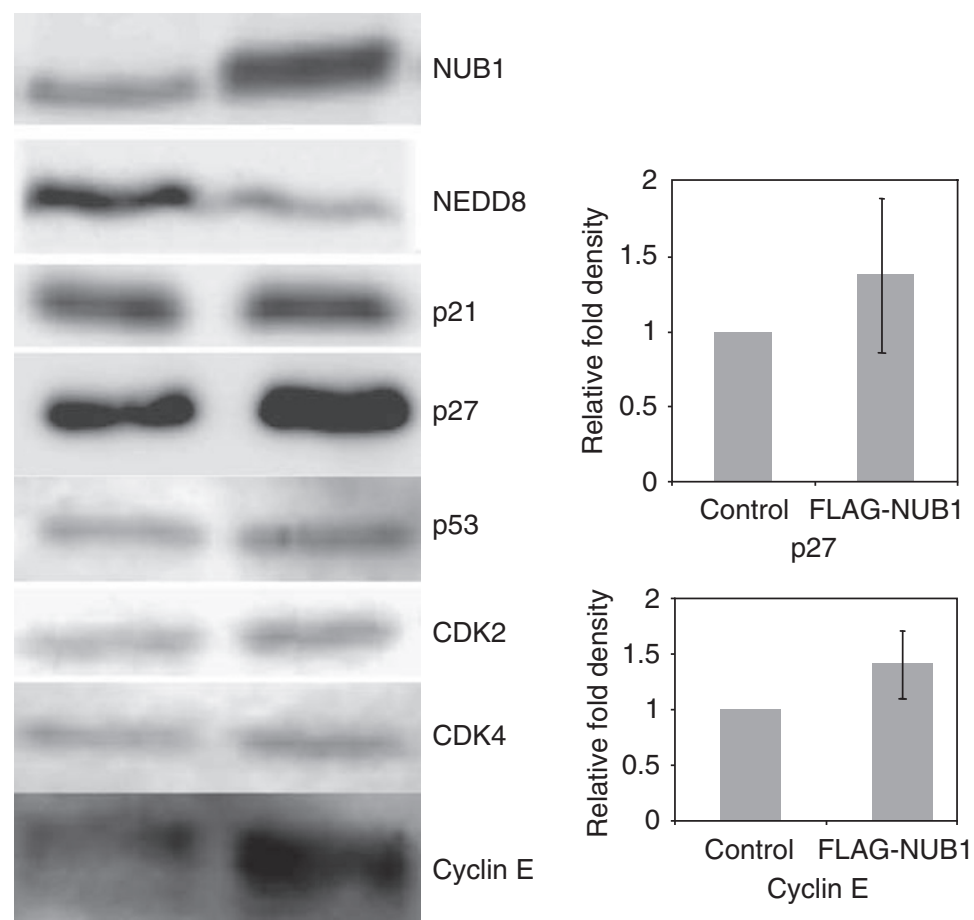

Cyclin D1

$\beta$-Actin

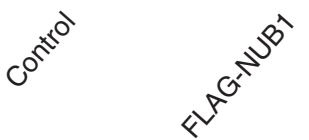

Figure 5 Effects of NEDD8 ultimate buster I (NUBI) overexpression on cell-cycle transition in A498 cells. A498 cells transfected with pcDNA3 (control) or pcDNA3/FLAG-NUBI were harvested $16 \mathrm{~h}$ after transfection and stained with propidium iodide (PI) as described in the Materials and Methods section. (A) The percentage of cells in each phase of the cell cycle was analysed by flow cytometry. Relative fluorescence intensities in a two-dimensional fluorescence-activated cell sorting (FACS) profile (ModFit LT software) in the control (left) or NUBI-overexpressing A498 cells (right) are presented. (B) As noted in the Materials and Methods section, cells were harvested $48 \mathrm{~h}$ after transfection and total cell lysates were prepared and analysed by western blot analysis using antibodies directed against the indicated proteins. Each experiment was performed in triplicate. The expression levels of p27 and cyclin E were normalised by the $\beta$-actin level and presented as the relative fold compared with the control. Data values were presented as means \pm s.d. 
cells with overexpression of NUB1 as compared with those in control cells (Figure 5B). There were no significant changes in the expression levels of other cell-cycle regulators. Moreover, overexpression of NUB1 decreased the expression of NEDD8 in A498 cells (Figure 5B). These results were reproduced in the same

A a
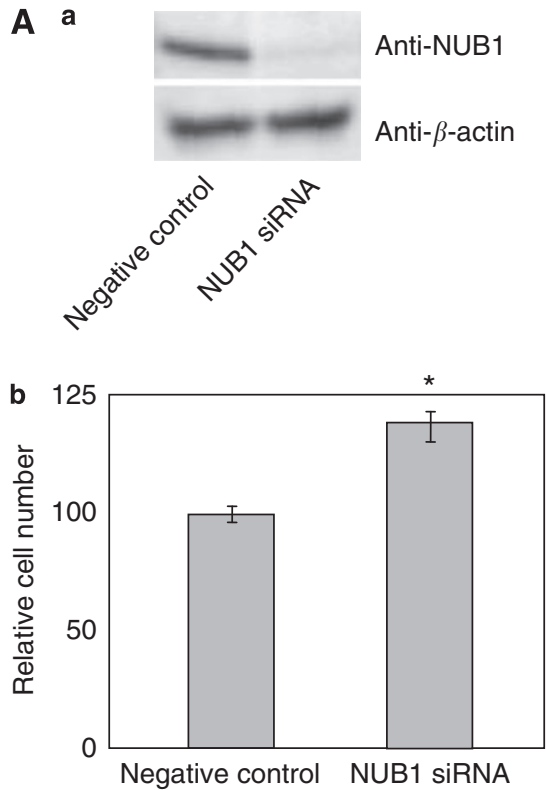

B a
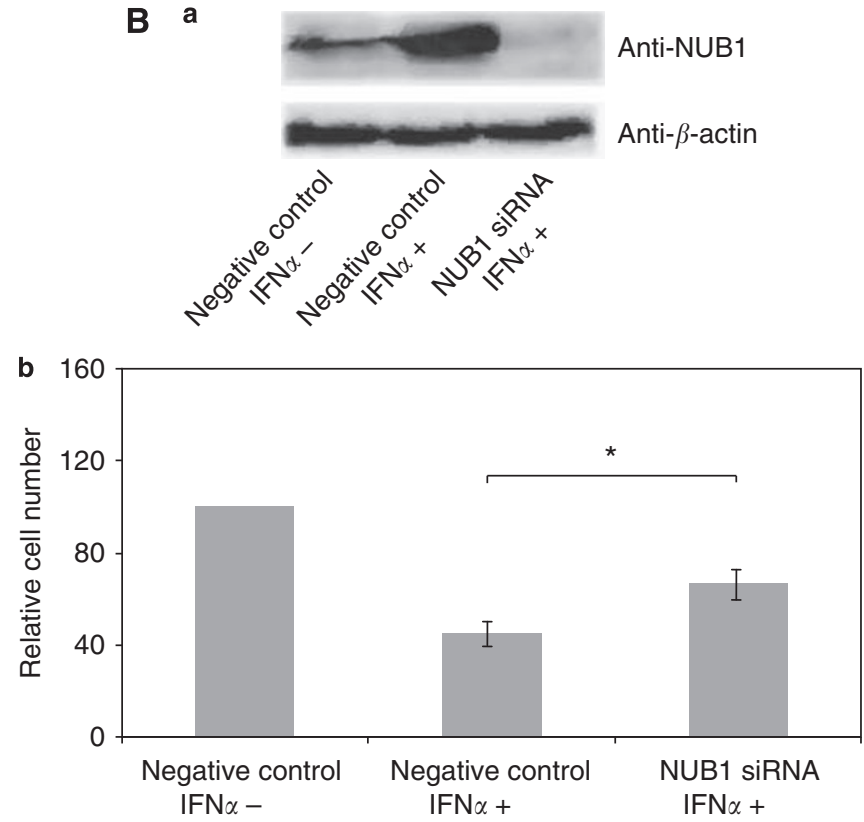

Figure 6 Knockdown of NEDD8 ultimate buster I (NUBI) expression promotes cell growth and suppresses interferon alpha (IFN- $\alpha$ )-induced inhibition of cell proliferation. (A, a) A498 cells transfected with negative control short interfering RNA (siRNA) (left) or NUBI siRNA (right) were harvested $72 \mathrm{~h}$ after transfection and total cell lysates were analysed by western blotting using an anti-NUBI antibody to evaluate the efficacy of NUBI siRNA. (B, a) IFN- $\alpha$-untreated 4THUR cells transfected with negative control (left), 4THUR cells, which were simultaneously treated with $1000 \mathrm{IU} \mathrm{ml}^{-1}$ IFN- $\alpha$ for $72 \mathrm{~h}$, transfected with negative control (middle) or NUBI siRNA (right) were followed up by the aforementioned analysis. (A, b; B, b) Viable cells were counted and the numbers were normalised on the basis of negative control cells. Three individual experiments were performed and the means \pm s.d. are presented *P $<0.05$ compared with the control (Student's t-test, $n=3$ ). analyses with overexpression of FLAG-NUB1L or caki-1 cells (data not shown).

\section{Downregulation of NUB1 promotes cell proliferation and suppresses IFN- $\alpha$-induced inhibition of cell growth}

We also investigated the effect of NUB1 knockdown on cell growth in RCC cells using the RNA interference technique. The efficiency of siRNA against NUB1(siNUB1) was determined by the extent of knockdown of NUB1 protein as compared with the expression level of endogenous NUB1 in control cells using western blot analysis. In A498 cells transfected with siNUB1, the amount of NUB1 protein was reduced to $<10 \%$ of that in control A498 cells (Figure 6A a). Knockdown of NUB1 clearly enhanced A498 cell growth, compared with control cells (Figure 6A b). Next, in IFN- $\alpha$ treated 4TUHR cells transfected with siNUB1, the amount of NUB1 protein was reduced to $<10 \%$ of that in control 4TUHR cells treated with IFN- $\alpha$ (Figure $6 \mathrm{~B}$ a). The number of control 4TUHR cells treated with IFN- $\alpha$ was decreased to $\sim 50 \%$ of that in control 4TUHR cells treated without IFN- $\alpha$. Knockdown of NUB1 partially suppressed IFN- $\alpha$-induced inhibition of 4TUHR cells (Figure 6B b).

\section{DISCUSSION}

NEDD8 has been reported to conjugate to a limited number of target proteins, including cullin family members (Cul-1, -2, -3, -4A, $-4 \mathrm{~B}$ and -5 ), von Hippel-Lindau protein (pVHL), murine double minute 2 (Mdm2), p53 and p73 (Kipreos et al, 1996; Wada et al, 1999; Read et al, 2000; Stickle et al, 2004; Xirodimas et al, 2004; Watson et al, 2006). Indeed, the NEDD8 conjugation system controls many biological events, including cell-cycle progression, tumorigenesis and neurodegeneration (Podust et al, 2000; Mori et al, 2005; Chairatvit and Ngamkitidechakul, 2007; Salon et al, 2007). Therefore, NUB1 is potentially involved in important biological functions through regulation of the NEDD8 conjugating system.

However, to our knowledge, there are no reports showing the basic mechanisms underlying the anti-tumour effects of NUB1 on cancer cells. First, we investigated whether NUB1 is induced by IFN- $\alpha$ in nine different human RCC cell lines. Expression levels of NUB1 mRNA and protein were upregulated by IFN- $\alpha$ in seven RCC cell lines, namely, ACHN, OS-RC-2, OCUU1, OCUU3, 786-0, 4 TUHR and 10RGB. Importantly, growth of these cell lines, except for 10RGB, was significantly inhibited by IFN- $\alpha$. A498, caki-1 and $10 \mathrm{RGB}$ were essentially resistant to IFN- $\alpha$ treatment. Most notably, in both A498 and caki-1cells, NUB1 expression levels were not significantly changed by IFN $-\alpha$. We demonstrated a positive significant correlation between IFN- $\alpha$-induced NUB1 expression and IFN- $\alpha$-induced cell growth inhibition in six out of the seven IFN- $\alpha$-sensitive cell lines, that is, in all but 10RGB. The slow proliferation of 10RGB cells might contribute to the lack of difference in cell viability between cells treated with IFN- $\alpha$ and untreated cells (as shown in Figure 1A). Next, we demonstrated that overexpression of NUB1 in two cell lines, A498 and caki-1, triggered cell-cycle alterations and apoptosis. Furthermore, we showed that NUB1 overexpression increased the cell population in the $S$ phase during the cell cycle and upregulated two ratedetermining components for cell-cycle transition (cyclin E and p27) and downregulated the expression of NEDD8. Previous studies defined various components in the fundamental pathways that regulate $\mathrm{G} 1-\mathrm{S}$ progression, including cyclin $\mathrm{D}$, cyclin $\mathrm{E}$ and their associated cyclin-dependent protein kinases (CDKs), including CDK4/6 and CDK2 (Koff et al, 1992; Sherr and Roberts, 1999). p27 is one of the CDK inhibitors that function as a major brake to the cell cycle and also induce apoptosis (Polyak et al, 1994; Vlach et al, 1996). Biologically, p27 mainly inhibits the activity of cyclin 
E-CDK2 complexes and thereby blocks progression from the G1 to the S phase (Sheaff et al, 1997). Interestingly, both p27 and cyclin $\mathrm{E}$ are major targets for the ubiquitination catalysed by the SCF complex. Thus, it is possible that NUB1 causes the S-phase transition and apoptosis, both of which are attributable to the inhibition of ubiquitination for p27 and cyclin E through a negative regulation of the NEDD8 conjugation system. Moreover, overexpression of NUB1L, an alternative splicing variant, induced S-phase arrest and apoptosis in the same series of experiments. As NUB1L also downregulates NEDD8 expression (Tanaka et al, 2003), one can speculate that NUB1L controls the expression levels of cyclin E and p27 through inhibition of NEDD8 expression, as well as that of NUB1. In addition, NUB1L has been reported to bind to FAT10 (one of the ubiquitin-like proteins), which induces apoptosis and regulates the cell cycle, and target FAT10 for degradation of 26S proteasome (Raasi et al, 2001; Hipp et al, 2004; Lim et al, 2006). In our used RCC cells, we could not detect an expression of FAT10 protein by western blotting (data not shown). It is possible that FAT10 does not have a crucial role in these RCC cells. Furthermore, some reports have shown that IFN- $\alpha$ induces $S$-phase arrest and apoptosis in liver cancer cell lines (Matsumoto et al, 2005; Yano et al, 2006). The positive correlation between
NUB1 induction and suppression of cell growth by IFN- $\alpha$ indicates that NUB1 could be a key molecule in IFN- $\alpha$-induced cell-cycle arrest and apoptosis in human RCC cells. Furthermore, knockdown of NUB1 remarkably increased proliferation in IFN- $\alpha$-resistant A498 cells and partly suppressed IFN- $\alpha-$ induced inhibition of cell proliferation in IFN- $\alpha$-sensitive 4TUHR cells.

On the basis of these experimental results, an altered expression of NUB1, which functions as a negative cell-cycle regulator, not only possibly correlates with IFN- $\alpha$-induced anti-mitogenic action, but might also yield anti-cancer effects against advanced RCC, against INF $\alpha$-resistant RCC as well.

\section{ACKNOWLEDGEMENTS}

We thank Dainippon Sumitomo Pharma Co. for providing us with natural human interferon alpha (HBLI). We also thank Ms Aiko Obayashi for her technical assistance. This work was supported by grants from the Ministry of Education, Science, and Culture of Japan.

\section{REFERENCES}

Amato RJ, Jac J, Giessinger S, Saxena S, Willis JP (2009) A phase 2 study with a daily regimen of the oral mTOR inhibitor RAD001 (everolimus) in patients with metastatic clear cell renal cell cancer. Cancer 115: $2438-2446$

Chairatvit K, Ngamkitidechakul C (2007) Control of cell proliferation via elevated NEDD8 conjugation in oral squamous cell carcinoma. Mol Cell Biochem 306: $163-169$

Escudier B, Eisen T, Stadler WM, Szczylik C, Oudard S, Siebels M, Negrier S, Chevreau C, Solska E, Desai AA, Rolland F, Demkow T, Hutson TE, Gore M, Freeman S, Schwartz B, Shan M, Simantov R, Bukowski RM (2007) Sorafenib in advanced clear-cell renal-cell carcinoma. N Engl J Med 356: 125-134

Hipp MS, Raasi S, Groettrup M, Schmidtke G (2004) NEDD8 ultimate buster-1L interacts with the ubiquitin-like protein FAT10 and accelerates its degradation. J Biol Chem 279: 16503-16510

Hudes G, Carducci M, Tomczak P, Dutcher J, Figlin R, Kapoor A, Staroslawska E, Sosman J, McDermott D, Bodrogi I, Kovacevic Z, Lesovoy V, Schmidt-Wolf IG, Barbarash O, Gokmen E, O’Toole T, Lustgarten S, Moore L, Motzer RJ (2007) Temsirolimus, interferon alfa, or both for advanced renal-cell carcinoma. $N$ Engl J Med 356: 2271-2281

Kamitani T, Kito K, Fukuda-Kamitani T, Yeh ET (2001) Targeting of NEDD8 and its conjugates for proteasomal degradation by NUB1. J Biol Chem 276: $46655-46660$

Kerbel RS (2008) Tumor angiogenesis. N Engl J Med 358: 2039-2049

Kipreos ET, Lander LE, Wing JP, He WW, Hedgecock EM (1996) cul-1 is required for cell cycle exit in $\mathrm{C}$. elegans and identifies a novel gene family. Cell 85: 829-839

Kito K, Yeh ET, Kamitani T (2001) NUB1, a NEDD8-interacting protein, is induced by interferon and down-regulates the NEDD8 expression. J Biol Chem 276: 20603-20609

Koff A, Giordano A, Desai D, Yamashita K, Harper JW, Elledge S, Nishimoto T, Morgan DO, Franza BR, Roberts JM (1992) Formation and activation of a cyclin E-cdk2 complex during the G1 phase of the human cell cycle. Science 257: 1689-1694

Lam JS, Leppert JT, Belldegrun AS, Figlin RA (2005) Novel approaches in the therapy of metastatic renal cell carcinoma. World J Urol 23: 202-212

Lim CB, Zhang D, Lee CG (2006) FAT10, a gene up-regulated in various cancers, is cell-cycle regulated. Cell Div 1: 20

Matsumoto K, Okano J, Murawaki Y (2005) Differential effects of interferon alpha- $2 \mathrm{~b}$ and beta on the signaling pathways in human liver cancer cells. J Gastroenterol 40: 722-732

Maxwell PH, Wiesener MS, Chang GW, Clifford SC, Vaux EC, Cockman ME, Wykoff CC, Pugh CW, Maher ER, Ratcliffe PJ (1999) The tumour suppressor protein VHL targets hypoxia-inducible factors for oxygen-dependent proteolysis. Nature 399: 271-275
McDermott DF, Regan MM, Clark JI, Flaherty LE, Weiss GR, Logan TF, Kirkwood JM, Gordon MS, Sosman JA, Ernstoff MS, Tretter CP, Urba WJ, Smith JW, Margolin KA, Mier JW, Gollob JA, Dutcher JP, Atkins MB (2005) Randomized phase III trial of high-dose interleukin-2 $v s$ subcutaneous interleukin-2 and interferon in patients with metastatic renal cell carcinoma. J Clin Oncol 23: 133-141

Mori F, Nishie M, Piao YS, Kito K, Kamitani T, Takahashi H, Wakabayashi K (2005) Accumulation of NEDD8 in neuronal and glial inclusions of neurodegenerative disorders. Neuropathol Appl Neurobiol 31: $53-61$

Motzer RJ, Bander NH, Nanus DM (1996) Renal-cell carcinoma. N Engl J Med 335: $865-875$

Motzer RJ, Hutson TE, Tomczak P, Michaelson MD, Bukowski RM, Rixe O, Oudard S, Negrier S, Szczylik C, Kim ST, Chen I, Bycott PW, Baum CM, Figlin RA (2007) Sunitinib vs interferon alfa in metastatic renal-cell carcinoma. N Engl J Med 356: 115-124

Negrier S, Escudier B, Lasset C, Douillard JY, Savary J, Chevreau C, Ravaud A, Mercatello A, Peny J, Mousseau M, Philip T, Tursz T (1998) Recombinant human interleukin-2, recombinant human interferon alfa-2a, or both in metastatic renal-cell carcinoma. Groupe Francais d'Immunotherapie. $N$ Engl J Med 338: $1272-1278$

Parkin DM, Bray F, Ferlay J, Pisani P (2005) Global cancer statistics, 2002. CA Cancer J Clin 55: 74-108

Podust VN, Brownell JE, Gladysheva TB, Luo RS, Wang C, Coggins MB, Pierce JW, Lightcap ES, Chau V (2000) A Nedd8 conjugation pathway is essential for proteolytic targeting of p27Kip1 by ubiquitination. Proc Natl Acad Sci USA 97: 4579-4584

Polyak K, Lee MH, Erdjument Bromage H, Koff A, Roberts JM, Tempst P, Massague J (1994) Cloning of p27Kip1, a cyclin-dependent kinase inhibitor and a potential mediator of extracellular antimitogenic signals. Cell 78: $59-66$

Raasi S, Schmidtke G, Groettrup M (2001) The ubiquitin-like protein FAT10 forms covalent conjugates and induces apoptosis. J Biol Chem 276: $35334-35343$

Read MA, Brownell JE, Gladysheva TB, Hottelet M, Parent LA, Coggins MB, Pierce JW, Podust VN, Luo RS, Chau V, Palombella VJ (2000) Nedd8 modification of cul-1 activates SCF(beta(TrCP))-dependent ubiquitination of IkappaBalpha. Mol Cell Biol 20: 2326-2333

Rini BI, Halabi S, Rosenberg JE, Stadler WM, Vaena DA, Ou SS, Archer L, Atkins JN, Picus J, Czaykowski P, Dutcher J, Small EJ (2008) Bevacizumab plus interferon alfa compared with interferon alfa monotherapy in patients with metastatic renal cell carcinoma: CALGB 90206. J Clin Oncol 26: 5422-5428

Salon C, Brambilla E, Brambilla C, Lantuejoul S, Gazzeri S, Eymin B (2007) Altered pattern of Cul-1 protein expression and neddylation in human 
lung tumours: relationships with CAND1 and cyclin E protein levels. J Pathol 213: $303-310$

Sheaff RJ, Groudine M, Gordon M, Roberts JM, Clurman BE (1997) Cyclin E-CDK2 is a regulator of p27Kip1. Genes Dev 11: $1464-1478$

Sherr CJ, Roberts JM (1999) CDK inhibitors: positive and negative regulators of G1-phase progression. Genes Dev 13: $1501-1512$

Singer JD, Gurian-West M, Clurman B, Roberts JM (1999) Cullin-3 targets cyclin $\mathrm{E}$ for ubiquitination and controls $\mathrm{S}$ phase in mammalian cells. Genes Dev 13: 2375-2387

Stickle NH, Chung J, Klco JM, Hill RP, Kaelin Jr WG, Ohh M (2004) pVHL modification by NEDD8 is required for fibronectin matrix assembly and suppression of tumor development. Mol Cell Biol 24: 3251-3261

Tanaka T, Kawashima H, Yeh ET, Kamitani T (2003) Regulation of the NEDD8 conjugation system by a splicing variant, NUB1L. J Biol Chem 278: $32905-32913$

Tanji K, Tanaka T, Mori F, Kito K, Takahashi H, Wakabayashi K, Kamitani T (2006) NUB1 suppresses the formation of Lewy body-like inclusions by proteasomal degradation of synphilin-1. Am J Pathol 169: $553-565$

Vlach J, Hennecke S, Alevizopoulos K, Conti D, Amati B (1996) Growth arrest by the cyclin-dependent kinase inhibitor p27Kip1 is abrogated by c-Myc. EMBO J 15: 6595-6604
Wada H, Yeh ET, Kamitani T (1999) Identification of NEDD8conjugation site in human cullin-2. Biochem Biophys Res Commun 257: $100-105$

Wang W, Nacusi L, Sheaff RJ, Liu X (2005) Ubiquitination of p21Cip1/ WAF1 by SCFSkp2: substrate requirement and ubiquitination site selection. Biochemistry 44: $14553-14564$

Watson IR, Blanch A, Lin DC, Ohh M, Irwin MS (2006) Mdm2-mediated NEDD8 modification of TAp73 regulates its transactivation function. J Biol Chem 281: 34096-34103

Xirodimas DP, Saville MK, Bourdon JC, Hay RT, Lane DP (2004) Mdm2-mediated NEDD8 conjugation of p53 inhibits its transcriptional activity. Cell 118: 83-97

Yano H, Yanai Y, Momosaki S, Ogasawara S, Akiba J, Kojiro S, Moriya F, Fukahori S, Kurimoto M, Kojiro M (2006) Growth inhibitory effects of interferon-alpha subtypes vary according to human liver cancer cell lines. J Gastroenterol Hepatol 21: 1720 - 1725

cc)(1) (2) This work is licensed under the Creative Commons NG SA Attribution-NonCommercial-Share Alike 3.0 License. To view a copy of this license, visit http://creativecommons.org/ licenses/by-nc-sa/3.0/ 